\title{
UPAYA MENINGKATKAN KOMPETENSI GURU MELALUI PELATIHAN PENELITIAN TINDAKAN KELAS
}

\author{
Happy Fitria ${ }^{1}$, Muhammad Kristiawan ${ }^{2 *}$, Nur Rahmat ${ }^{3}$ \\ ${ }^{1}$ Jurusan Manajemen Pendidikan,Universitas PGRI Palembang \\ Jl. Jend Ahmad Yani, Lr. Gotong Royong, 9/10 Ulu, Kota Palembang, Sumatera Selatan 30116 \\ ${ }^{2}$ Jurusan Ilmu Pendidikan, Universitas Bengkulu \\ Jl. Wr. Supratman, Kandang Limun, Muara Bangka Hulu, Kota Bengkulu, Bengkulu 38371 \\ ${ }^{3}$ Jurusan Manajemen Pendidikan, Universitas PGRI Palembang \\ J1. Jend Ahmad Yani, Lr. Gotong Royong, 9/10 Ulu, Kota Palembang, Sumatera Selatan 30116 \\ *Email: Muhammad.kristiawan@yahoo.co.id
}

\begin{abstract}
Abstrak
Penelitian ini bertujuan untuk meningkatkan kompetensi guru SD dan SMP Negeri/Swasta di Kabupaten Ogan Ilir provinsi Sumatera Selatan. Peningkatan kompetensi guru dilakukan melalui Penelitian Tindakan Kelas (PTK). Pelatihan Penelitian Tindakan Kelas (PTK) dilakukan dengan strategi siklus yang dilakukan dengan tahapan dari identifikasi masalah, perencanaan, tindakan, observasi, dan refleksi. Berdasarkan identifikasi masalah bahwa masih banyak guru yang mengalami kesulitan dalam menyusun PTK dan melaksanakannya di kelas. Lemahnya kemampuan mereka dalam menyusun PTK disebabkan oleh keterbatasan pengetahuan atau pemahaman mereka tentang PTK secara praktek. Teknik pengumpulan data dalam penelitian ini menggunakan observasi, wawancara dan evaluasi. Dalam pelatihan menunjukkan bahwa para guru berpartisipasi aktif untuk memiliki keseriusan, kemauan, dan motivasi yang tinggi untuk mengembangkan penelitian tindakan kelas. Dalam meningkatkan keberhasilan pada proses pembelajaran salah satunya melalui penelitian tindakan kelas (PTK). Manfaat PTK di antaranya adalah membantu guru memperbaiki mutu pembelajaran, meningkatkan profesionalisme guru dan meningkatkan kompetensi guru. Kegiatan pelatihan Penelitian Tindakan Kelas ini memberikan dampak terhadap peningkatan pengetahuan yang signifikan tentang pemahaman penelitian tindakan kelas, pengolahan dan analisis data penelitian tindakan kelas. Hasil akhir dalam penelitian ini adalah proses pelatihan memberikan manfaat bagi guru, yaitu dapat meningkatkan pemahaman guru pada Penelitian Tindakan Kelas, menumbuhkan motivasi dalam menyusun PTK dan melaksanakan PTK, serta bagi sekolah dapat meningkatkan kinerja sekolah melalui peningkatan profesionalisme guru. Hasil dari penelitian ini dapat dijadikan sebagai bahan masukan guru di sekolah lainnya sebagai upaya untuk meningkatkan kompetensi guru melalui Penelitian Tindakan Kelas.
\end{abstract}

Kata Kunci: Kompetensi Guru; Profesionalisme Guru; Penelitian Tindakan Kelas.

\section{PENDAHULUAN}

Kualitas pendidikan yang ada di negera kita Indonesia ini memang masih jauh dari yang diharapkan, maka perlu upaya kerja keras dan terus menerus untuk mengejar ketertinggalannya sehingga nantinya akan mampu berkompetisi secara terhormat dalam era globalisasi. Sondakh (2007) dalam upaya meningkatkan kualitas pendidikan maka diperlukan orang-orang ahli pada bidangnya, sesuai dengan kapasitas yang dimilikinya agar setiap orang dapat berperan secara maksimal, termasuk guru sebagai sebuah profesi yang menuntut kecakapan dan keahlian tersendiri. Guru merupakan profesi atau pekerjaan yang memerlukan keahlian khusus atau profesionalisme guru. Arti dari profesional adalah sebuah profesi yang tidak dapat dilakukan oleh sembarangan orang Usman (2006). Guru memiliki peran yang strategis dalam upaya meningkatkan kualitas pendidikan sehingga ada slogan no teacher, no education yang berarti tidak ada guru, tidak ada pendidikan. Dengan kata lain guru merupakan komponen kunci dalam upaya peningkatan kualitas 
pendidikan dan menjadi salah satu penentu keberhasilan pendidikan, seperti membentuk watak bangsa dan mengembangkan potensi siswa dalam kerangka pembangunan pendidikan di Indonesia.

Hadirnya guru pada saat ini sampai akhir zaman nanti tidak akan pernah dapat digantikan oleh teknologi secanggih apapun. Oleh karena itu, dalam melaksanakan tugas-tugas guru yang cukup komplek dan unik maka diperlukan guru yang memiliki kemampuan yang maksimal untuk mewujudkan tujuan pendidikan nasional dan diharapkan secara kontinyu guru dapat meningkatkan kompetensinya. Guru merupakan kunci keberhasilan pendidikan. Dengan tugas profesional dan didukung oleh kompetensi pedagogiknya, guru berfungsi membantu peserta didik untuk belajar dan berkembang, membantu perkembangan intelektual, personal dan social warga masyarakat yang memasuki sekolah (Cooper, 1982). Untuk dapat melaksanakan tugas tersebut dengn baik, selain harus memenuhi syarat-syarat kedewasaan, sehat jasmani dan rohani, guru juga harus memiliki ilmu dan kecakapan-keterampilan keguruan, wawasan kependidikan (pedagogik) dan kecakapan keterampilan tersebut diperoleh selama menempuh pelajaran di lembaga pendidikan guru (Sukmadinata, 2005).

Guru merupakan pihak pemegang kunci dari menarik serta efektif tidaknya suatu proses pembelajaran, karena itu seorang guru tidak hanya di tuntut mampu menghidupkan suasana kelas tetapi juga mampu untuk menjadikan pembelajaran menjadi suatu proses dalam peningkatan kepribadian bagi peserta didik. Undang-Undang Nomor 20 Tahun 2003 pasal 40 ayat $2 \mathrm{~b}$ tentang Sisdiknas, guru sebagai ujung tombak dalam proses pendidikan sangat strategis dan menentukan dalam meningkatkan mutu pendidikan. Upaya dalam meningkatkan kualitas pendidik dan tenaga kependidikan untuk menyelesaikan masalah yang dihadapi saat menjalankan tugasnya guru akan memberi dampak positif yaitu pertama, penyelesaian masalah pendidikan dan pembelajaran melalui sebuah investigasi terkendali akan dapat meningkatkan kualitas isi, masukan, proses, dan hasil belajar; kedua, kemampuan dalam menyelesaikan masalah pendidikan yang nyata akan semakin meningkat; dan ketiga, peningkatan profesionalisme pendidik dan tenaga kependidikan lainnya. Guru profesional akan terlihat melalui tanggung jawabnya sebagai seorang guru dalam melaksanakan seluruh pengabdiannya. Guru profesional mampu memikul dan melaksanakan tanggung jawabnya kepada peserta didik, orang tua, masyarakat, bangsa, negara dan agamanya. Guru profesional mempunyai tanggung jawab sosial diwujudkan melalui kompetensi guru dari lingkungan sosial serta memiliki kemampuan interaktif yang efektif.

Guru wajib memiliki kualifikasi akademik, sertifikasi pendidik, kompetensi, sehat jasmani dan rohani, serta memiliki kemampuan untuk mewujudkan tujuan pendidikan nasional. Kompetensi guru merupakan kemampuan dari seorang guru dalam melaksanakan kewajiban-kewajibannya secara bertanggung jawab dan layak. Sudrajad (2007) seorang guru yang inovatif, produktif, dan kreatif merupakan guru yang selalu mencari dan menemukan hal-hal baru dan mutakhir untuk kepentingan kualitas pembelajaran di kelas. Guru yang berkompenten dan profesional adalah guru yang piawi dalam melaksanakan profesinya (Syah, 2000). Guza (2008) mengatakan bahwa standar kompetensi guru meliputi empat kompetensi utama, adalah 1) kompetensi pedagogik; 2) kompetensi kepribadian; 3) kompetensi social; dan 4) kompetensi profesional. Jika diperhatikan dengan cermat maka kompetensi guru tersebut ternyata mempunyai hubungan yang saling berkaitan agar terwujudnya kompetensi guru yang optimal. Kompetensi profesionalisme guru terdapat dalam Depdiknas (2004) "kompetensi profesional meliputi pengembangan profesi, pemahaman wawasan, dan penguasaan bahan kajian akademik". Guru yang memiliki kompetensi tinggi adalah orang yang memiliki kemampuan dan keahlian khusus dalam bidang keguruan, sehingga Ia mampu melakukan tugas dan fungsinya sebagai guru dengan kemampuan yang maksimal (Usman, 2006).

Dalam masyarakat Indonesia peran guru tetap dominan sekalipun teknologi yang dapat dimanfaatkan dalam proses pembelajaran berkembang sangat cepat. Ini disebabkan karena ada dimensi dalam proses pendidikan, atau lebih khusus bagi proses pembelajaran, yang diperankan oleh 
guru yang tidak dapat digantikan oleh teknologi (Sa'ud, 2010). Syarat terjadinya proses pembelajaran adalah peserta didik dan guru, alat dan sumber belajar dijadikan sebagai sarana penunjang yang akan mempermudah guru dalam proses pembelajaran untuk memperoleh lulusan yang berkualitas. Sudiana (2013) menyatakan bahwa dalam rangka pengembangan profesional, guru tidak bisa melepaskan dirinya dari kegiatan akademik penelitian. Penelitian yang terkait langsung dengan tugas pokok dan fungsinya serta berdampak langsung terhadap peningkatan kualitas pembelajaran adalah Penelitian Tindakan Kelas. Penelitian yang dimaksudkan dalam konteks ini, ruang lingkupnya berada di seputar kelas, yaitu penelitian di kelasnya sendiri yang biasa disebut Penelitian Tindakan Kelas atau PTK (Graha Pusaka, 2012).

Paizaluddin \& Ermalinda (2015) Penelitian Tindakan Kelas (PTK) berasal dari bahasa inggris Classroom Action Research, yang artinya penelitian yang dilakukan pada sebuah kelas untuk mengetahui akibat tindakan yang diterapkan pada suatu objek penelitian dalam kelas tersebut. Secara empiris, guru yang berpengalaman mengajar secara tidak disadari telah melakukan sejumlah kegiatan tambahan yang tidak tercantum dalam satuan pelajaran tetapi ia telah melaksanakan Penelitian Tindakan Kelas.

Penelitian Tindakan Kelas (PTK) atau classroom action research merupakan upaya yang digunakan dalam upaya memperbaiki atau meningkatkan mutu pembelajaran. Penelitian Tindakan Kelas merupakan model pengembangan profesi dimana guru mempelajari cara siswa belajar dalam kaitannya dengan cara guru mengajar, sehingga guru dapat memperbaiki kekurangannya dalam mengajar agar berdampak pada perbaikan proses belajar siswa. PTK dapat dimanfaatkan untuk meningkatkan kemampuan guru melakukan refleksi diri, meningkatkan kemajuan sekolah, dan menumbuhkan budaya profesional di kalangan pendidik. Dengan demikian bahwa Penelitian Tindakan Kelas merupakan pengembangan profesi guru dimana seorang guru dapat melakukan Penelitian Tindakan Kelas yang disebut dengan kegiatan ilmiah seorang guru mengembangkan inovasinya dalam pembelajaran seperti menggunakan metode, strategi media demi meningkatkan kompetensi profesionalnya.

Dalam kegiatan PTK ini, guru memiliki peran strategis dalam pengembangan kompetensi profesional sekaligus sebagai upaya dalam meningkatkan dan memperbaiki proses maupun hasil belajar siswa. Kristiawan, dkk (2017) kompetensi profesional guru dapat diperoleh melalui pendidikan profesional dan memahami instruksi dibantu dengan komputer (Kristiawan, 2014). Kompetensi guru dalam melaksanakan Penelitian Tindakan Kelas adalah bagian dari kompetensi profesional yang guru harus mampu serta kuasai dalam melaksanakan Penelitian Tindakan Kelas. Guru perlu melaksanakan Penelitian Tindakan Kelas dikarenakan dengan melaksanakan PTK ini maka akan diperoleh manfaat ganda yaitu memperbaiki dalam proses pembelajaran dan meningkatkan kemampuan guru dalam kegiatan pengembangan profesi.

Menurut Aqib (2007) Penelitian Tindakan Kelas adalah suatu kebutuhan bagi guru untuk meningkatkan kompetensi guru sebab Penelitian Tindakan Kelas sangat kondusif untuk membuat guru menjadi peka dan tanggap terhadap dinamika pembelajaran di kelasnya. Dengan melaksanakan tahapan dalam Penelitian Tindakan Kelas yang sistematik dan berkesinambungan, guru mampu memperbaiki proses pembelajaran melalui suatu kajian yang dalam terhadap apa yang terjadi di kelasnya. Dengan demikian para guru menjadi reflektif dan kritis terhadap apa yang dia dan muridnya lakukan.

Selain itu, Penelitian Tindakan Kelas dapat meningkatkan kinerja guru sehingga menjadi profesional. Guru tidak lagi sebagai praktisi, yang hanya merasa puas dengan apa yang dikerjakan tanpa adanya perbaikan dan inovasi, namun juga sebagai peneliti di bidangnya dan juga pelaksanaan PTK didasarkan pada masalah aktual dan faktual yang berkembang di kelasnya dan tidak mengganggu tugas pokok seorang guru karena dia tidak perlu meninggalkan kelasnya sebab PTK merupakan suatu kegiatan penelitian yang terintegrasi dengan pelaksanaan proses pembelajaran. 
PTK sendiri mampu meningkatan pengetahuan yang signifikan mengenai pemahaman terhadap Penelitian Tindakan Kelas, pengolahan dan analisis data (Sunendiari, dkk, 2014). PTK menjadi cerminan tindakan yang sengaja dimunculkan oleh guru atau dengan arahan guru yang dilakukan oleh siswa (Suwandi, 2011: 12). PTK dapat dimanfaatkan untuk meningkatkan kemampuan guru melakukan refleksi diri, meningkatkan kemajuan sekolah, dan menumbuhkan budaya professional di kalangan pendidik.

Tampubolon (2014) juga menjelaskan bahwa Penelitian Tindakan Kelas menjadi kebutuhan utama para pendidik dalam rangka memperbaiki/meningkatkan kualitas kinerjanya yang akan berdampak positif terhadap 1) peningkatan kemampuan dalam menyelesaikan masalah pendidikan dan masalah pembelajaran yang dihadapi secara nyata; 2) peningkatan kualitas masukan, proses, dan hasil belajar baik akademik maupun nonakademik; 3) peningkatan profesionalisme pendidik; dan 4) penerapan prinsip pembelajaran berbasis penelitian dan berkelanjutan. Saat ini Penelitian Tindakan Kelas (PTK) memang mendapatkan perhatian yang cukup besar dalam dunia pendidikan. Pemerintah juga secara khusus setiap tahun memberikan dana bagi guru yang mampu merencanakan dan melakukan PTK dengan baik (Depdiknas, 2008).

Peneitian Tindakan Kelas semakin mendapatkan prioritas untuk bisa dilakukan guru, mengingat adanya manfaat ganda dari PTK sebagai berikut 1) pelaksanaan PTK yang terencana dan terkendali secara baik, akan meningkatkan kinerja guru dalam mengelola pembelajaran yang berkualitas; 2) penyelesaian masalah kelas atau pembelajaran akan memberikan perbaikan pada kualitas proses pembelajaran; dan 3) perbaikan peran guru dalam pembelajaran akan mampu memberikan kontribusi bagi peningkatan kualitas pendidikan secara nasional. Hal ini sesuai dengan pendapat Santyasa (2007) yang menyatakan bahwa PTK sangat mendukung program peningkatan kualitas pembelajaran di sekolah, yang bermuaranya adalah pada peningkatan kualitas pendidikan.

PTK disamping memberikan manfaat bagi peningkatan kualitas pembelajaran maupun kualitas pendidikan, laporan PTK juga sangat bermanfaat bagi guru yang bersangkutan dalam hal kenaikan pangkat dan kredit pengembangan profesi keguruan. Sesuai dengan peraturan Mendiknas dan Kepala BAKN Nomor 03/V/PB/2010 dan Nomor 14 Tahun 2010 tentang petunjuk pelaksanaan jabatan fungsional guru dan angka kreditnya, guru diwajibkan untuk mengembangkan diri, melaksanakan publikasi ilmiah dan melaksanakan karya inovatif.

Sejak tanggal 1 Januari 2013 bahwa syarat kenaikan pangkat/jabatan guru dari III/b ke pangkat jabatan lebih tinggi wajib melaksanakan kegiatan pengembangan diri dan publikasi ilmiah yang antara lain dari hasil PTK. Selaras dengan kebijakan sertifikasi guru, karya pengembangan profesi dalam bentuk PTK juga merupakan salah satu butir penting penentu keberhasilan guru dalam meraih sertifikasi. Dengan demikian, kegiatan meneliti maupun menulis, mau tidak mau, suka tidak suka, harus dilakukan oleh guru. Guru yang profesional perlu melaksanakan Penelitian Tindakan Kelas karena hasil penelitian ini akan merupakan informasi yang sangat berharga bagi keberhasilan dirinya sebagai pengajar untuk digunakan dalam perbaikan dan penyempurnaan tugas-tugas profesinya. Agar pelaksanaan Penelitian Tindakan Kelas memberikan manfaat seperti yang diharapkan, maka guru harus 1) mengidentifikasi masalah;2) menentukan permasalahan yang akan dipecahkan; 3) menyusun rancangan penelitian; 4) melaksanakan; dan 5) tindak lanjut apa yang seharusnya dilakukan setelah diadakan Penelitian Tindakan Kelas.

Bagi seorang pendidik yang akan melakukan Penelitian Tindakan Kelas, pada dasarnya pendidikan atau guru sudah mengetahui bayak permasalah-permalahan yang ada dalam pembelajaran tinggal bagaimana mengemas ke dalam sistematika penulisan sebagaimana yang tetalah ditetapkan dalam komponen penelitian tindakan kelas. Pada dasarnya seorang pendidik/guru sudah melakukan Penelitian Tindakan Kelas, meskipun rancangan, pelaksanaan dan evaluasinya belum sesuai dengan format Penelitian Tindakan Kelas, demikian pula hasil temuan mereka belum dilaporkan sesuai dengan pedoman yang sudah ditetapkan. 
PTK dilaksanakan dalam pembelajaran biasa, tidak ada kelas khusus untuk melakukan PTK, karena pada hakekatnya PTK dilakukan oleh guru sendiri di kelasnya (Tampubolon, 2014: 19). Pemerintah saat ini telah mengeluarkan peraturan dalam upaya meningkatkan profesionalisme guru secara berkelanjutan yang menekankan bahwa pengembangan keprofesian berkelanjutan (PKB) adalah pengembangan kompetensi pendidik yang dilaksanakan sesuai dengan kebutuhan, bertahap, dan berkelanjutan untuk meningkatkan profesionalitasnya melalui Permenpan no 16 tahun 2009. PKB ini terdiri dari tiga kegiatan, yaitu 1) pengembangan diri dalam bentuk (a) mengikuti diktat fungsional dan (b) melaksanakan kegiatan kolektif pendidik; 2) publikasi ilmiah dalam bentuk (a) membuat publikasi ilmiah atas hasil penelitian dan (b) membuat publikasi buku; dan 3) karya inovatif dalam bentuk (a) menemukan teknologi tepat guna; (b) menemukan/menciptakan karya seni; (c) membuat/memodifikasi alat pembelajaran dan media pembelajaran; dan (d) mengikuti pengembangan penyusunan standar, pedoman, kriteria, prosedur, dan penyusunan butir soal penilaian yang valid serta reliabel. Bagi seorang pendidik menyusun Penelitian Tindakan Kelas mungkin bisa jadi merupakan suatu langkah yang sulit, bahkan tidak sedikit yang tidak dapat melakukannya dengan baik, namun demikian apabila pendidik atau guru dalam melakukan proses penelitian, dalam peneliti melukiskan bahwa mereka telah mengetahui apa yang akan dilakukan, bagaimana cara melakukan serta menjelaskan mengapa penelitian tersebut perlu dilakukan.

Berdasarkan hasil wawancara di lapangan pada tanggal 2 Agustus 2018 dengan beberapa guru dan kepala sekolah, di ketahui bahwa kondisi guru SD dan SMP Negeri/Swasta di Kabupaten Ogan Ilir provinsi Sumatera Selatan, bahwa masih banyak guru yang mengalami kesulitan dalam menyusun PTK dan melaksanakannya di kelas. Lemahnya kemampuan mereka dalam menyusun PTK disebabkan oleh keterbatasan pengetahuan atau pemahaman mereka tentang PTK secara praktek. Sebagian besar dari mereka belum memiliki pemahaman yang baik mengenai PTK sehingga permasalahan-permasalahan yang dihadapi di kelas, tidak mampu mereka tuangkan dalam bentuk tulisan untuk dilakukan penelitian guna memperoleh solusinya. Pelatihan Penelitian Tindakan Kelas yang pernah diikuti selama ini hanya sebatas memberikan pemahaman terhadap konsep dasar Penelitian Tindakan Kelas saja. Permasalahan yang dihadapi oleh para guru sekarang adalah belum banyak guru yang mengenal PTK (Graha Pusaka, 2012).

Kurangnya pemahaman guru juga berimbas pada terhambatnya proses kenaikan pangkat karena kurangnya komponen penelitian yang mesti mereka lakukan. Pada dasarnya hal ini disebabkan oleh faktor terbatasnya pengetahuan guru tentang PTK baik yang menyangkut diagnosis dan penetapan masalah, bentuk dan skenario tindakan, maupun prosedur pelaksanaan PTK. Dalam upaya untuk meningkatkan kompetensi guru SD dan SMP Negeri/Swasta di Kabupaten Ogan Ilir melalui penulisan PTK, maka perlu dilakukan dengan memberikan pelatihan PTK yang sesuai dengan kebutuhan guru, melibatkan guru secara aktif dalam perencanaan, pelaksanaan, dan menilai hasil pelatihan, serta mendampingi secara intensif guru-guru tersebut hingga mampu menyusun atau menghasilkan PTK dengan baik.

\section{METODE}

Metode pelaksanaan pelatihan ini menggunakan pendekatan penelitian tindakan. Creswell (2012) menyebutkan action research are systematic procedures done by teachers to gather information about, and subsequently improve, the ways their particular educational setting operates, theirteaching, and their student learning. Ary (2010) penelitian tindakan adalah melakukan tindakan berdasarkan penelitian dan meneliti tindakan yang diambil. Langkah-langkah dalam penelitian tindakan ini meliputi perencanaan tindakan, pelaksanaan tindakan, observasi, dan refleksi (Suyadi, 2010).

a. Perencanaan 
Perencanaan adalah langkah pertama dalam melaksanaan penelitian tindakan. Perencanaan harus dilaksanakan secara matang dan teliti. Dalam perencanaan terdapat tiga dasar, yaitu identifikasi masalah, merumuskan masalah, dan pemecahan masalah. Pada masing-masing kegiatan, terdapat sub-sub kegiatan yang sebaiknya dilaksanakan untuk menunjang sempurnanya tahap perencanaan. Untuk itu dilakukan kegiatan studi dokumentasi, diskusi dengan guru, melakukan pengamatan awal. Setelah disepakati permasalahan utama dan solusi pemecahan masalah, dilakukan kegiatan penyusunan instrumen penelitian bagi peneliti dan rencana pembelajaran bagi guru yang akan disupervisi. Kegiatan perencanaan siklus kedua dan selanjutnya dilakukan diskusi dengan guru yang akan disupervisi berkenaan dengan hasil pelaksanaan kegiatan refleksi siklus sebelumnya. Dengan kegiatan ini akan dilakukan upaya peningkatan kualitas dengan meningkatkan kekuatan dan mengganti kelemahan yang terjadi dengan kekuatan yang lain.

b. Pelaksanaan

Pelaksanaan dalam penelitian tindakan adalah dengan menerapkan apa yang telah direncanakan pada tahap satu, yaitu bertindak di kelas. Pada pelaksanaan ini penelitian tindakan harus sesuai dengan rencana, terkesan alamiah dan tidak direkayasa.

c. Observasi

Observasi adalah alat untuk memotret seberapa jauh efek tindakan telah mencapai sasaran. Observasi dilakukan bersamaan dengan pelaksanaan kegiatan. Pada tahap inilah diperlukan seorang pengamat yang siap merekam setiap peristiwa yang berkaitan dengan tindakan peneliti. Selain merekam setiap peristiwa yang berkaitan dengan tindakan peneliti, pengamat sebaiknya juga membuat catatan-catatan kecil agar memudahkan dalam menganalisis data.

d. Refleksi

Refleksi adalah kegiatan untuk mengemukakan kembali apa yang telah dilakukan. Refleksi juga sering disebut dengan istilah "memantul". artinya akan tampak jelas penglihatannya, baik kelemahan dan kekurangannya. Refleksi atau evaluasi diri baru bisa dilakukan ketika pelaksanaan tindakan telah selesai dilakukan. Refleksi akan berjalan lebih efektif apabila peneliti yang melakukan tindakan berhadapan langsung atau diskusi dengan pengamat atau kolabolator. Hasil refleksi akan memberikan gambaran kekuatan dan kelemahan yang terjadi. Hasil ini akan dijadikan bahan pertimbangan penyusunan perencanaan siklus selanjutnya.

Teknik pengumpulan data menggunakan wawancara untuk memperoleh data tentang kesulitan guru dalam menyusun PTK, observasi untuk mengamati implementasi model pelatihan dan evaluasi terhadap PTK untuk memperoleh data keberhasilan dari implementasi model pelatihan. Indikator keberhasilan penelitian adalah guru mampu menghasilkan proposal PTK dengan kriteria baik. Objek penelitian adalah guru SD dan SMP Negeri/Swasta di kabupaten Ogan Ilir yang berjumlah kurang lebih 50 orang. Sedangkan waktu pelaksanaan pelatihan selama 6 hari dimulai dari tanggal 02 sampai dengan 08 Agustus 2018.

\section{HASIL DAN PEMBAHASAN}

Pada tahap pelatihan pemberian materi sistematika penyusunan Penelitian Tindakan Kelas dan materi pelaksanaannya para peserta sangat antusias, hal ini terlihat dari peserta yang mengikuti kegiatan sampai akhir. Indikator lainnya adalah suasana terlihat hidup dengan adanya sesi tanya jawab dan diskusi tentang beberapa tahapan dari Penelitian Tindakan Kelas, seperti deskripsi kondisi awal, dan deskripsi hasil siklus antara pelatih dengan Bapak Ibu guru SD dan SMP Negeri/Swasta di kabupaten Ogan Ilir yang berjumlah kurang lebih 50 orang yang mengikuti kegiatan ini. Dengan adanya pelatihan ini para guru terlihat bersemangat dalam memulai Penelitian Tindakan Kelas. Upaya yang dilakukan pelatih pada prinsipnya lebih ditekankan pada memotivasi dan melibatkan 
kegiatan peserta pelatihan. Oleh karena itu model pelatihan ini dianggap lebih efektif karena para guru dilibatkan secara aktif berlatih dan berkarya menghasilkan PTK tidak hanya mendengarkan ceramah yang hanya bersifat transfer pengetahuan, didampingi pelatih yang selalu mengarahkan dan memotivasi hingga guru benar-benar mampu menyusun PTK yang merupakan hasil refleksi dari permasalahan pembelajaran di kelasnya. Pelatihan Penelitian Tindakan Sekolah ini difokuskan pada upaya meningkatkan kompetensi guru melalui PTK bagi guru di SD dan SMP Negeri/Swasta di kabupaten Ogan Ilir melalui penerapan model pelatihan dengan pendampingan intensif.

Permasalahan yang hendak dijawab adalah apa saja kesulitan yang dihadapi guru-guru dalam menyusun PTK dan bagaimana penerapan model pelatihan partisipatif dengan pendampingan intensif untuk meningkatkan kompetensi guru melalui PTK serta bagaimana hasil penerapan model pelatihan tersebut. Penelitian Tindakan Kelas akan sangat kondusif untuk membuat guru menjadi lebih peka dan tanggap pada sebuah dinamika pembelajaran di kelas.

Penelitian Tindakan Kelas dapat meningkatkan kinerja guru sehingga guru menjadi lebih profesional. Guru perlu melakukan upaya perbaikan inovasi namun dia bisa menempatkan dirinya sebagai peneliti di bidangnya. Penelitian Tindakan Kelas dimaksudkan untuk mengatasi suatu permasalahan yang terdapat di dalam kelas. Guru perlu menjadi peneliti untuk mengetahui apa penyebab munculnya masalah. Sekurang-kurangnya lima manfaat penelitian tindakan kelas menurut Fraenkel, dkk (2012) yaitu sebagai berikut 1) PTK dapat dilakukan oleh hampir semua ahli di semua tipe sekolah, semua level, guru kelas baik secara individu maupun berkelompok, ataupun pimpinan sekolah; 2) PTK membantu guru mengidentifkasi masalah-masalah dan isu-isu secara sistematis; 3) PTK memberikan ruang kepada para guru atau praktisi lainnya untuk mengadakan penelitian mereka sendiri sehingga guru dapat mengembangkan cara yang lebih efektif untuk mempraktikkan keahlian mereka; 4) PTK dapat memperbaiki praktik pendidikan; membantu praktisi pendidikan (guru, pimpinan sekolah) dalam meningkatkan kompetensi terhadap apa yang mereka lakukan; dan 5) PTK dapat membangun sebuah komunitas yang berorientasi penelitian ilmiah di dalam sekolah itu sendiri.

Penelitian tindakan kelas ini akan berdampak terhadap profesi yaitu 1) Pengakuan terhadap peran sebagai pengembang pengetahuan dan sumbangan bagi wacana dan teori dalam penelitian pendidikan; 2) Pengembangan staf secara professional; dan 3) Terjalinnya jaringan para praktisi yang melakukan PTK untuk mengeratkan kesejawatan dan meningkatkan kualitas profesi (Depdikbud, 1999). Penelitian Tindakan Kelas ini akan meningkatkan kompetensi guru, jika dilaksanakan di kelas secara sadar dan sistematik. Jika Penelitian Tindakan Kelas dilaksanakan secara sadar dan sistematis diharapkan kompetensi guru akan meningkat karena guru akan selalu berusaha memperbaiki kegiatan pembelajaran yang berarti guru akan meningkat kompetensinya. Wiriaatmadja (2005) mengungkapkan kompetensi guru tidak akan meningkat dengan sendirinya tetapi tentu ada upaya untuk meningkatkannya. Kompetensi guru dapat ditingkatkan melalui berbagai cara antara lain mengikuti pendidikan dan latihan, sertifikasi guru, dan Penelitian Tindakan Kelas. Pendidikan di dalam pelaksanaannya akan muncul gagasan atau permasalahan guru yang diuji dan dikembangkan dalam bentuk tindakan. Dari pengalaman melakukan Penelitian Tindakan Kelas, guru menyadari kekurangannya dan berusaha untuk memperbaiki dan meningkatkan keterampilannya. Guru sadar akan perlunya upaya-upaya pembaharuan atau inovasi untuk mendukung kegiatan-kegiatan perbaikan.

Melalui pengalaman melakukan penelitian, guru memahami hubungan antara gagasan atau teori dengan praktik mengajar guru dan belajar siswa dalam kesehariannya, dan kesadaran ini akan menumbuhkan rasa percaya diri yang apabila terus dikembangkan akan meningkatkan harga diri. Penelitian Tindakan Kelas merupakan kebutuhan guru untuk meningkatkan profesionalitasnya sebagai seorang guru hal ini dikarenakan yaitu sebagai berikut 1) Penelitian tindakan kelas sangat kondusif untuk membuat guru menjadi peka dan tanggap terhadap dinamika pembelajaran di 
kelasnya; 2) Penelitian tindakan kelas meningkatkan kinerja guru sehingga guru menjadi profesional; 3) Guru mampu memperbaiki proses pembelajaran melalui suatu pengkajian yang terdalam terhadap apa yang terjadi di kelasnya; dan 4) Penelitian tindakan kelas tidak mengganggu tugas pokok seorang guru karena dia tidak perlu meninggalkan kelasnya (Sukanti, 2008). Penelitian ini juga didukung oleh penelitian Nitiasih (2010) tentang implementasi model pelatihan PTK Reflektif Berbasis Kompetensi yang menunjukkan bahwa model pelatihan yang pada prinsipnya menekankan pada partisipasi guru-guru dapat meningkatkan kemampuan guru-guru dalam menyusun proposal PTK berdasarkan hasil refleksi terhadap pembelajarannya.

Di samping itu pembimbingan/pendampingan secara langsung dan intensif dapat mengoptimalkan kemampuan guru dalam menyusun PTK, sebagaimana ditunjukkan oleh hasil penelitian Martono (2009) yang menyatakan bahwa metode tutorial yang diterapkan pada proses pembelajaran Diklat PTK dapat mengoptimalkan kemampuan guru- guru dalam menyusun PTK.

Dalam kegiatan pembelajaran guru sebagai pengembang kurikulum karena Penelitian Tindakan Kelas yaitu 1) merupakan sebuah proses yang diprakarsai guru untuk menanggapi situasi praktis tertentu yang harus mereka hadapi; 2) situasi tersebut merupakan pelaksanaan bagian dari kurikulum yang terganggu dan menimbulkan persoalan bagi guru karena misalnya penolakan dari peserta didik yang tidak mau belajar; 3) apabila tindakan dalam penelitian tindakan kelas itu merupakan upaya inovasi pembelajaran dan ternyata menimbulkan respon yang kontroversal di kalangan staf guru atau lainnya karena dipandang bertentangan dengan hakikat belajar mengajar dan evaluasi selama ini maka penelitian tindakan kelas dapat membantu memberikan kepastian tentang manfaatnya kepada staf guru tersebut; 4) permasalahan atau isu-isu yang didiskusikan berlangsung dalam wacana yang bebas dan terbuka, ditandai oleh rasa menghormati dan toleransi pendapat orang lain dan tidak dibatasi oleh wewenang pimpinan dalam menerima hasil-hasil penelitian; 5) proporsal penelitian yang mengusulkan perubahan dianggap sebagai hipotesis kerja yang akan diujikan terlebih dulu dalam praktik sebagai pertanggungjawaban atau akuntabilitas terhadap staf pengajar lainnya; dan 6) penelitian ini merupakan pendekatan yang akar rumput sifatnya memakai pendekatan boton-up dalam mengembangkan kebijakan atau strategi pengembangan kurikulum yang seyogyanya difasilitasi oleh pimpinan lembaga pendidikan yang bersangkutan (Wiriaatmadja, 2005).

Sebelum dilakukan pelatihan guru di SD dan SMP Negeri/Swasta di kabupaten Ogan Ilir menyatakan masih banyak yang mengalami kesulitan dalam menyusun PTK sebagai tahap persiapan dalam melaksanakan PTK dan kesulitan menyusun PTK tersebut mencakup semua aspek. Tahap penelitian dari setiap siklus di mulai dari perencanaan, tindakan, observasi, dan refleksi. Kesulitan dalam menyusun PTK ini disebabkan karena guru-guru belum memiliki pemahaman yang jelas tentang PTK dan cara menyusun PTK yang benar, serta tidak berani mencoba karena takut salah. Setelah dilakukan pelatihan guru mulai mampu menyusun PTK sesuai dengan sistematika yang baik dan benar.

Pada awal pelaksanaan pelatihan kepada guru di SD dan SMP Negeri/Swasta di kabupaten Ogan Ilir terlebih dahulu diberikan dan dijelaskan materi tentang konsep PTK dan cara menyusun PTK oleh pakar/pelatih dengan metode pembelajaran yang tidak hanya ceramah tetapi lebih menekankan pada tanya jawab, diskusi dan pemberian contoh. Dilanjutkan dengan kegiatan menyusun rencana awal PTK dan PTK dengan pembimbingan/ pendampingan secara kelompok/ klasikal dari pelatih. Selama proses penyusunan PTK interaksi antara guru dan pendamping dalam bentuk diskusi, tanya jawab, pengarahan dan motivasi. Semua peserta tampak antusias, serius, tekun, dan aktif mengikuti kegiatan pelatihan hingga berhasil menyusun PTK. Hal ini ditunjukkan bahwa guru di SD dan SMP Negeri/Swasta di kabupaten Ogan Ilir sudah mulai mempunyai pemahaman yang cukup baik sesuai sistematika penyusunan PTK. Walau demikian masih ada juga kekurangan atau kesalahan di bagian/aspek tertentu. Agar kekurangan atau kesalahan dalam menyusun bagian dari PTK tersebut dapat diperbaik maka perlu dilakukannya tindakan perbaikan pada siklus II, 
sehingga kedepannya peserta pelatihan dapat menghasilkan proposal PTK dengan kriteria baik. Melalui pendampingan kepada setiap peserta diharapkan guru dapat lebih memahami dan mengetahui secara detail dari setiap bagian PTK yang harus diperbaiki dan dilengkapi serta bagaimana perbaikannya. Hasil siklus II menunjukkan bahwa kemampuan guru di SD dan SMP Negeri/Swasta di kabupaten Ogan Ilir dalam menyusun PTK makin meningkat. Kekurangan dan kesalahan dalam menyusun pada setiap bagian ataupun aspek tertentu bisa diperbaiki dan dilengkapi.

Berdasarkan uraian di atas diharapkan bahwa dengan melaksanakan penelitian tindakan kelas maka akan dapat meningkatkan kompetensi guru. Dalam peningkatan kompetensi guru melalui penelitian tindakan kelas dapat dijelaskan melalui tiga hal yaitu sebagai berikut 1) identifikasi permasalahan yang dijumpai guru dalam proses pembelajaran dan upaya memperbaikinya; 2) materi yang dikaji dalam penelitian tindakan kelas; dan 3) pelaksanaan penelitian tindakan kelas. Penelitian tindakan kelas ini akan meningkatkan kompetensi guru, jika dilaksanakan di kelas secara sadar dan sistematik, namun tentunya tidak semua kompetensi dapat ditingkatkan tetapi hanya subkompetensi tertentu saja seperti 1) memahami gaya belajar dan kesulitan belajar peserta didik; 2) menguasai teori dan prinsip belajar serta pembelajaran yang mendidik; 3) mengembangkan kurikulum yang mendorong keterlibatan peserta didik dalam pembelajaran; 4) merancang pembelajaran yang mendidik; 5) mengevaluasi kinerja sendiri; 6) mengevaluasi proses dan hasil pembelajaran; 7) melaksanakan pembelajaran yang mendidik; 8) mengembangkan diri secara berkelanjutan; 9) menguasai struktur bidang studi dan materi kurikulum bidang studi; 10) menguasai substansi bidang studi dan metodologi keilmuannya; 11) menguasai dan memanfaatkan teknologi informasi dan komunikasi dalam pembelajaran; 12) mengorganisasikan materi kurikulum bidang studi; dan 13) meningkatkan kualitas pembelajaran.

Model pelatihan Penelitian Tindakan Kelas ini prinsipnya adalah melibatkan peserta pelatihan yaitu guru SD dan SMP Negeri/Swasta di kabupaten Ogan Ilir dengan semaksimal mungkin dalam pelatihan mulai identifikasi kebutuhan, perencanaan, pelaksanaan, sampai evaluasi pelatihan. Jadi, pelatihan ini diselenggarakan berdasarkan kebutuhan guru, direncanakan, dilaksanakan, dan dievaluasi dengan melibatkan partisipasi aktif dari guru-guru, agar hasilnya betul-betul sesuai dengan kebutuhan dan harapan guru. Pelatihan ini pada prinsipnya lebih ditekankan pada motivasi dan melibatkan kegiatan peserta. Penggunaan model pelatihan PTK secara kelompok/klasikal maupun secara individual telah dapat mengatasi permasalahan kesulitan guru dalam menyusun PTK. Minat, rasa percaya diri, dan kompetensi guru-guru dalam menyusun PTK semakin meningkat. Melalui pendampingan intensif dari pelatih, guru-guru berani mencoba dan tidak takut salah dalam menyusun PTK, sehingga guru-guru dapat menghasilkan PTK yang akan diimplementasikan dalam penelitian di sekolahnya dengan kriteria baik berdasarkan 10 aspek yang dinilai.

Aspek yang dinilai meliputi 10 aspek dengan masing-masing aspek terdiri dari empat deskriptor yaitu latar belakang masalah, rumusan masalah, tujuan penelitian, manfaat hasil penelitian, kajian teoritis/pustaka, kerangka berpikir, hipotesis tindakan, metode penelitian, jadwal penelitian, dan daftar pustaka. Hal ini sesuai dengan pendapat Badu (2012) bahwa peran pelatih adalah sebagai fasilitator yang harus memaksimalkan kinerja peserta pelatihan. Guru-guru merespon positif pelatihan dan pendampingan ini karena pelatihan ini memberikan waktu dan bimbingan yang cukup yang mereka butuhkan untuk menyusun sebuah penelitian yang baik serta benar-benar bermanfaat dalam membangun pengetahuan dan pemahaman mereka tentang konsep-konsep Penelitian Tindakan Kelas. Didukung juga oleh penelitian sebelumnya dari Nitiasih (2010) yang menunjukkan adanya peningkatan kemampuan guru-guru dalam membuat proposal PTK melalui implementasi model pelatihan PTK Reflektif Berbasis Kompetensi karena model pelatihan ini pada prinsipnya menekankan pada partisipasi guru-guru untuk membuat proposal PTK berdasarkan hasil refleksi terhadap pembelajarannya. 


\section{KESIMPULAN DAN SARAN}

\section{Kesimpulan}

Pelatihan PTK ini dianggap sangat penting dan perlu untuk melatih guru dalam melakukan penelitian sebagai salah satu solusi mengatasi permasalahan yang ada di kelas tempat mengajar. Kegiatan pelatihan PTK juga sebagai upaya untuk melatih guru agar terampil dalam membuat karya tulis ilmiah. Dilaksanakan pelatihan PTK pada guru SD dan SMP Negeri/Swasta di Kabupaten Ogan Ilir berhasil memperlihatkan sikap antusias peserta sehingga kegiatan berjalan dengan baik serta menghasilkan produk PTK dengan judul yang beragam. PTK yang telah disusun oleh guru dapat diimplementasikan dalam penelitian di sekolah/kelasnya. Penyusunan PTK dalam bentuk jurnal akan bermanfaat bagi peningkatan kepangkatan atau jabatan fungsional guru. Hasil penelitian ini diharapkan memberikan manfaat bagi guru, yaitu menumbuhkan motivasi dalam menyusun PTK dan melaksanakan PTK, serta bagi sekolah dapat meningkatkan kinerja sekolah melalui peningkatan profesionalisme guru. Hasil dari penelitian ini dapat dijadikan sebagai bahan masukan guru di sekolah lainnya sebagai upaya untuk meningkatkan kompetensi guru melalui Penelitian Tindakan Kelas.

\section{Saran}

Seorang guru yang profesional harus selalu mengembangkan diri untuk memenuhi tuntutan dalam tugasnya sebagai pendidik. Sebagai guru yang profesional salah satu alternatif untuk mengembangkan diri adalah dengan Penelitian Tindakan Kelas. Penelitian Tindakan Kelas dapat meningkatkan kompetensi guru dapat dtinjau dari masalah yang dikaji, bidang kajian, pelaksanakan Penelitian Tindakan Kelas yang meliputi perencanaan, pelaksanaan, pengamatan, dan refleksinya. Masalah yang dikaji adalah masalah yang ditemukan guru, guru peduli terhadap permasalahan yang muncul dalam kegiatan pembelajaran dan guru berupaya untuk memperbaikinya. Jika guru melaksanakan Penelitian Tindakan Kelas maka akan meningkat kompetensinya, karena guru menemukan masalah, berupaya mencari penyebab munculnya masalah, mencari alternatif pemecahannya, melaksanakan Penelitian Tindakan Kelas, mengamati pelaksanaan tindakan dan mengadakan refleksi. Jika Penelitian Tindakan Kelas ini dilaksanakan secara sadar dan sistematik yang dilakukan di kelas akan meningkatkan kompetensinya.

\section{Ucapan Terima Kasih}

Kami mengucapkan terima kasih kepada Rektor Universitas PGRI Palembang (Dr. H. Bukman Lian, M.M, M.Si) yang telah memberikan kesempatan dan menyetujui hibah PKM kami yaitu pelatihan PTK bagi SD dan SMP Negeri/Swasta di Kabupaten Ogan Ilir. Selanjutnya, kami ucapkan terima kasih kepada Direktur Program Pascasarjana (Dr. H. Houtman, M.Pd.) dan Ketua LPPkM (Dr. Rohana, M.Pd.) yang telah membantu menyelesaikan pelatihan ini.

\section{DAFTAR PUSTAKA}

Aqib, Z. (2007). Penelitian Tindakan Kelas. Bandung: Yrama Widya.

Ary, D., et, \& al. (2010). Introduction to Research in Education (8th ed). Wadsworth: Cengage Learning.

Badu, A. M. (2012). Pengembangan Model Pelatihan Pendampingan Dalam Rangka Peningkatan Kompetensi Pendamping Pada Kelompok Usaha Konveksi di Kota Gorontalo. Tesis. Bandung: Program Pascasarjana UPI.

Cooper, A. (1982). World of logotype (Annual). New York: Art Direction Book Company. 
Creswell, W. j. (2012). Education Research: Planing, Conducting, and Evaluating Quantitative and Qualitative Research (4th ed). Boston: Pearson Education.

Departemen Pendidikan dan Kebudayaan. (1999). Bahan Pelatihan Penelitian Tindakan Kelas. Jakarta: Direktorat Jendral Pendidikan Dasar dan Menengah Direktorat Pendidikan Menengah Umum.

Depdiknas. (2008). Pedoman Block Grant penelitian Tindakan Kelas.

Direktorat Pembinaan Penelitian dan Pengabdian Kepada Masyarakat . (2004). Panduan Penataran dan Lokakarya Penelitian Tindakan Kelas Bagi Dosen LPTK se-Indonesia. Solo: Dikti-Diknas.

Fraenkel, J. R., et, \& al. (2012). How to Design and Evaluate Research in Education (8th) . New York: Mc Graw-Hill Companies, inc.

Graha Pustaka. (2012). Penelitian Guru Minim LIPI: Guru Kekurangan Waktu Meneliti Karena Mengajar. diakses pada grahapusaka.blogspot.com pada tanggal 13 Agustus 2018.

Guza, A. (2008). Himpunan Permendiknas Tentang Standar Pendidikan dan Tenaga Kependidikan . Jakarta: Asa Mandiri.

Kristiawan, M. (2014). A Model for Upgrading Theacher Competence on Operating Computer as Assistant of Instruction. Global Jurnal of Human-Social Science Research. Vol XIV. Issue V. Version I.

Kristiawan, M., Safitri, D., \& Lestari, R. (2017). Manajemen Pendidikan. Yogyakarta: Deepublish.

Martono, B. (2009). Optimalisasi Kemampuan Penyusunan Proposal Penelitian Tindakan Kelas (PTK) Melalui Metode Tutorial bagi Guru SMK Peserta Diklat di PPPPTK BOE Malang. Malang: Jurnal Online PPPPTK BOE. Kementerian Pendidikan dan Kebudayaan Pusat Pengembangan dan Pemberdayaan Pendidik Bidang otomotif dan Elektronika. Diakses dari www.vedcmalang.com/pppptkboemlg/index.php /departemen -bangunan-30/1138-budi-m pada 13 Agustus 2018.

Nitiasih, P., Padmadewi, N. N., \& Sutama, L. P. (2010). Pengembangan Model Pelatihan Penelitian Tindakan Kelas Refleksi Berbasis Kompetensi. Jurnal Penelitian dan Pengembangan Pendidikan. Vol 4 No. 3 Hal 252-266.

Paizaludin, \& Ermalinda. (2015). Penelitian Tindakan Kelas (Classroom Action Research). Bandung: Alfabeta.

Peraturan Bersama Mendiknas dan Kepala BKN Nomor : 03/V/PB/2010 Nomor : 14 Tahun 2010 tentang Petunjuk Pelaksanaan Jabatan Fungsional Guru Dan Angka Kreditnya ini mulai berlaku pada tanggal ditetapkan dan berlaku efektif pada tanggal 1 Januari 2013.

Peraturan Menteri Negara Pendayagunaan Aparatur Negara Dan Reformasi Birokrasi Nomor 16 Tahun 2009 Tentang Jabatan Fungsional Guru Dan Angka Kreditnya.

Santyasa, I. W. (2007). Metodologi Penelitian Tindakan Kelas (makalah disampaikan dalam Pendidikan dan Pelatihan Metodologi Penelitian, Penyusunan Proposal, dan Penulisan Karya Ilmiah bagi Guru-Guru SMP dan SMA/SMK di Kabupaten Buleleng di Univ. Pendidikan Ganesha Singaraja).

Sa'ud, U. S. (2010). Pengembangan Profesi Guru. Bandung: Alfabeta.

Sondakh, A. (2007). Membangun Profesionalisme Guru. diakses dari www.angelinasondakh.com pada tanggal 12 Agustus 2018.

Sudiana, I. N. (2013). Penelitian Tindakan Kelas (makalah disampaikan dalam Pelatihan Penyusunan Proposal Tindakan Kelas bagi Guru-Guru Bahasa Indonesia pada tanggal 8 Juli 2013. di SMAN 2 Semarapura.

Sudrajad, A. (2007). Kompetensi Guru dan Kepala Sekolah. diakses dari www.akhmadsudrajad07.wordpress.com pada tanggal 12 Agustus 2018.

Sukanti. (2008). Meningkatkan Kompetensi Guru Melalui Pelaksanaan Penelitian Tindakan Kelas. Jurnal Pendidikan Akuntansi Indonesia Vol. VI No. 1 - Tahun 2008 Hal 1- 11. Universitas Negeri Yogyakarta.

Sukmadinata, N. S. (2005). Metode Penelitian Pendidikan. Bandung: Remaja Rosdakarya.

Sunendiari, S., Yanti, T. S., A., A. I., \& Suliadi. (2014). Pelatihan Penelitian Tindakan Kelas Bagi Guru-Guru SMA Di Wilayah Bandung dalam Upaya Meningkatkan Kompetensi Guru. Bandung: In Prosiding SNaPP2014 Sains, Teknologi, dan Kesehatan. Universitas Islam Bandung (pp. 7-14). 
Suwandi, S. (2011). Penelitian Tindakan Kelas (PTK) dan Penulisan Karya Tulis Ilmiah. Surakarta: Yuma Pustaka.

Suyadi. (2010). Panduan Penelitian Tindakan Kelas. Yogyakarta: Diva Press.

Syah, M. (2000). Psikologi Pendidikan dengan Pendekatan Baru. Bandung: Remaja Rosdakarya.

Tampubolon. (2014). Penelitian Tindakan Kelas Sebagai Pengembangan Profesi Pendidik dan Keilmuan. Jakarta: Erlangga.

Undang-undang Republik Indonesia No. 20 Tahun 2003. Sistem Pendidikan Nasional. Jakarta: Asokadikta dan Durat Bahagia.

Usman, M. U. (2006). Menjadi Guru Profesional. Bandung: Remaja Rosdakarya.

Wiriaatmadja, R. (2005). Metode Penelitian Tindakan Kelas Untuk Meningkatkan Kinerja Guru dan Dosen. Bandung: Remaja Rosdakarya. 